\title{
Aplikasi Pencatatan Perhitungan Laba Rugi Berbasis Desktop pada PT. Fachri Syafii Akbar
}

\author{
Akhsani Taqwiym ${ }^{[1]}$, Nurasiah ${ }^{[2]}$ \\ Sistem Informasi, STMIK GI MDP ${ }^{[1]}$, Komputerisasi Akuntansi, STMIK GI MDP ${ }^{[2]}$ \\ Jalan Rajawali No. 14, Palembang \\ Akhsani.taqwiym@mdp.ac.id ${ }^{[1]}$, nurasiah@mhs.mdp.ac.id ${ }^{[2]}$
}

\begin{abstract}
Application of profit and loss is implemented from the problems that occur at PT. Fachri Syafii Akbar where in the PT there was a problem in recording the report so that sometimes the contents of the report did not match the recording in the admin section and expenditure in the field. This application was created to assist in the process of recording activity reports in the process of completing a project of PT Fachri Syafii Akbar so that there is no difference in the final report, otherwise the application will display the entire history of transactions in and out of transactions during the project. The methodology used is the waterfall method and the implementation of the needs analysis. From the results of field observations, an information flow design was obtained which was then implemented by making a program using Microsoft Visual Basic.Net 2013 and MySQL. The results achieved are the creation of a periodic application in recording the process of project completion activities until the final report.
\end{abstract}

Keywords-Calculation of Profit and Loss; Microsoft Visual Basic.Net 2013; MySQL

Abstrak-- Aplikasi laba rugi merupakan diimplementasi dari permasalahan yang terjadi pada PT. Fachri Syafii Akbar dimana pada PT tersebut terjadi permasalahan dalam pencatatan laporan sehingga terkadang isi laporan tidak sesuai dengan pencatatan di bagian admin dan pengeluaran di lapangan. Aplikasi ini dibuat untuk membantu dalam proses pencatatan laporan kegiatan dalam proses penyelesaian suatu proyek PT Fachri Syafii Akbar agar tidak terjadi selisih pada laporan akhir selain itu aplikasi akan menampilkan seluruh riwayat keluar masuknya transaksi selama proyek berjalan. Metodologi yang digunakan yaitu metode waterfall dan implementasi dari analisis kebutuhan. Dari hasil observasi lapangan diperoleh sebuah rancangan alur informasi yang kemudian diimplementasi dengan membuat program menggunakan Microsoft Visual Basic.Net 2013 dan MySQL. Hasil yang dicapai adalah terciptanya aplikasi secara berkala dalam mencatat proses kegiatan penyelesaian proyek hingga laporan akhirnya.

Kata kunci-Perhitungan Laba Rugi; Microsoft Visual Basic.Net 2013; MySQL

\section{PENDAHULUAN}

Perusahaan kontruksi adalah perusahaan yang bergerak dalam bidang jasa dimana perusahaan menjalankan usaha dibidang pekerjaan kontruksi, baik pelaksana kontruksi maupun sebagai konsultan kontruksi. PT Fachri Syafii Akbar merupakan perusahaan kontruksi yang bergerak dalam bidang pembangunan jalan, listrik, dan lainnya. Perusahaan ini sudah terbentuk pada tahun 2013 yang beralamatkan di Jalan. Dr. M. Isa Lr. Idaman No. 18 Rt. 27 Rw. 07 Palembang. Struktur organisasi di PT. Fachri Syafii Akbar dipimpin oleh satu orang pimpinan dan dibantu dengan beberapa staf seperti admin, koordinator lapangan, dan staf yang membantu dikantor.

Pencatatan laba rugi pada sebuah perusahaan jika dicatat secara manual bukanlah sebuah masalah dikarenakan pencatatan secara manual data tetap tercatat dan terdokumentasi dengan baik [1]. Namun ada kalanya pencatatan secara manual, terjadi kesalahan input bahkan tidak tercatat. Pencatatan yang dilakukan adalah kegiatan transaksi yang terjadi pada proses penyelesaian proyek. Transaksi usaha adalah kejadian yang dapat mempengaruhi posisi keuangan dari suatu badan usaha dan juga sebagai hal yang handal dan wajar untuk dicatat tiga transaksi ini biasanya dibuktikan dengan adanya dokumen. Sebagai contoh transaksi yang dapat terjadi dalam suatu perusahaan adalah pembayaran rekening telepon bulanan, pembelian barang dagangan secara kredit, pembelian tanah dan gedung, dan lain sebagainya. [2] Hal ini akan mempengaruhi hasil perhitungan. Pencatatan secara manual menimbulkan banyak kekurangan dari efisien waktu, kesalahan pencatatan akibat kesalahan manusia dan lain sebagainya. Teknologi berkembang dengan tujuan mempermudah pekerjaaan manusia terutama dalam proses pencatatan laba rugi pada sebuah perusahaan. Berdasarkan hasil observasi dilapangan pencatatan yang terjadi pada PT Fachri Syafii Akbar dilaksanakan oleh bagian administrasi yang selanjutnya dalam sistem disebut admin. Tugas bagian administrasi adalah mendokumentasikan kontrak yang telah disetujui dan ditanda tangani oleh pimpinan dan pihak klien. Kemudian nominal nilai kontrak akan menjadi acuan harga sebuah proyek yang akan diproses dalam penyelesaian kontrak tersebut. Dalam penyelesaian kontrak ini, akan terjadi transaksi dimana barang ataupun alat yang akan digunakan dalam penyelesaian proyek di beli dan akan menjadi tercatat sebagai stok bahan baku. Tentunya bahan baku akan terjadi proses keluar dan masuk. Kejadian keluar masuknya barang ini akan mempengaruhi keuangan. Keuangan yang dimaksud adalah nilai kontrak akan berkurang dengan adanya proses penyelesaian proyek. Proses berkurangnya nominal inilah yang nantinya akan terlihat pada akhir laporan penyelesaian proyek jika terdapat selisih kelebihan dana proyek 
maka itu merupakan keuntungan bagi perusahaan namun jika terjadi sebaliknya maka disebut kerugian bagi perusahaan. Dalam proses yang terjadi transaksi keluar masuknya barang sering terjadi kesalahan hal ini dikarenakan nota yang terkadang tidak tercatat, pengadaan barang yang terlambat, nota yang tercecer, ataupun admin yang tidak mencatat. Hal-hal ini menimbulkan selisih sehingga menyebabkan laporan akhir yaitu laporan laba rugi penyelesaian proyek memerlukan waktu dalam proses penyusunan dan pencatatan untuk mencatat kegiatan yang tidak tercatat. Pencatatan laba rugi adalah jumlah yang berasal dari pengurangan harga pokok produksi, biaya lain, dan kerugian dari penghasilan atau penghasilan operasi. [3] Tentunya hal ini menyebabkan masalah dalam pengambilan keputusan untuk pimpinan mengetahui proyek yangs sedang ataupun telah selesai dikerjakan mendapatkan keuntung atau kerugian.

Untuk membantu mengatasi permasalahan pada PT Fachri Syafii Akbar dibuatlah sebuah aplikasi berbasis desktop yang menadaptasi kegiatan informasi yang terjadi pada PT Fachri Syafii Akbar. Dalam aplikasi yang akan dibuat, akan dikendalikan oleh admin yang merupakan orang yang mendokumentasikan kegiatan yang terjadi secara manual kemudian akan beralih kedalam sistem desktop. Kegiatan yang dilakukan secara manual diadaptasi sedemikian rupa sama dengan kegiatan pencatatan manual sehingga admin tidak akan merasakan kesulitan pada saat menggunakan aplikasi desktop tersebut. Dalam aplikasi desktop admin akan dapat melakukan pencatatan input kontrak kemudian input data yang diperlukan dan input data keluar. Proses input yang telah diinput oleh admin akan tersimpan dalam database kemudian akan telihat sebagai riwayat. Dari riwayat yang diinput oleh admin secara sistem akan terbaca laporan kegiatan dari proyek diinput hingga selesai dengan keluaran sebagai file pdf. Dari file pdf ini, pimpinan dapat melihat proyek tersebut mendapatkan keuntungan atau kerugian pada saat penyelesaian. Pada aplikasi desktop pimpinan mendapatkan hak akses untuk melihat kinerja admin, serta pimpinan dapat melihat laporan kegiatan langsung tanpa harus mengkonfrimasi kepada admin. Tentunya data yang dapat dilihat telah diinput terlebih dahulu oleh admin.

Untuk merancang aplikasi desktop digunakan metode waterfall dari analisis kebutuhan, desain, pembuatan kode program, pengujian, pendukung atau pemeliharan [4]. Metode waterfall adalah seatu proses pengembangan perangkat lunak berurutan, dimana kemajuan dipandang sebagai ters mengalir kebawah (seperti air terjun) melewati fase-fase perencanaan, pemodelan, implementasi (kontruksi), dan pengujian. Dengan adanya aplikasi berbasis desktop ini diharapkan dapat memudahkan pimpinan dalam memantau dan mendapatkan informasi mengenai proyek yang sedang berlangsung dan telah selesai. Untuk admin diharapkan dengan adanya aplikasi ini admin dapat dipermudah dalam proses pencatatan transaksi proyek dan memudahkan dalam pelaporan proyek sehingga laporan akurat dan sesuai dengan kejadian dilapangan.

Oleh karena permasalahan yang ada di PT Fachri Syafii Akbar di nilai dengan secara subjektif yaitu,pencatatan kegiatan transaksi yang tidak terdokumentasi dengan baik sehingga menyebabkan selisih pada laporan akhir. Bagaimana menyelesaikan permasalahan yang manual dengan bantuan teknologi sehingga menghasilkan proses yang lebih baik. Laporan keuangan merupakan ringkasan dari suatu proses pencatatan, merupakan suatu ringkasan transaksi-transaksi keuangan yang terjadi selama tahun buku yang bersangkutan. Laporan keuangan disusun berdasarkan data yang relevan, serta dilakukan dengan prosedur akuntansi dan penilaian yang benar, akan terlihat kondisi keuangan perusahaan sesungguhnya yang meliputi jumlah harta (kekayaan), kewajiban (utang) serta modal (ekuitas) dalam neraca yang dimiliki.[5]

Tujuan dari penelitian ini adalah membuat aplikasi berbasis desktop dengan mengadaptasi kegiatan manual yang terjadi di PT Fachri Syafii Akbar sehinga memudahkan admin dan pimpinan menggunakan aplikasi tersebut sehingga apliksi berbasis desktop ini dapat membantu dan menyelesaikan permasalahan yang terjadi pada PT Fachri Syafii Akbar.

\section{BAHAN DAN METODE}

\section{A. Kerangka Pemikiran}

Pada penelitian dengan judul aplikasi pencatatan perhitungan laba rugi berbasis desktop pada PT Fachri Syafii Akbar digambarkan seperti 1 yang menunjukkan pemikiran pada penelitian ini.

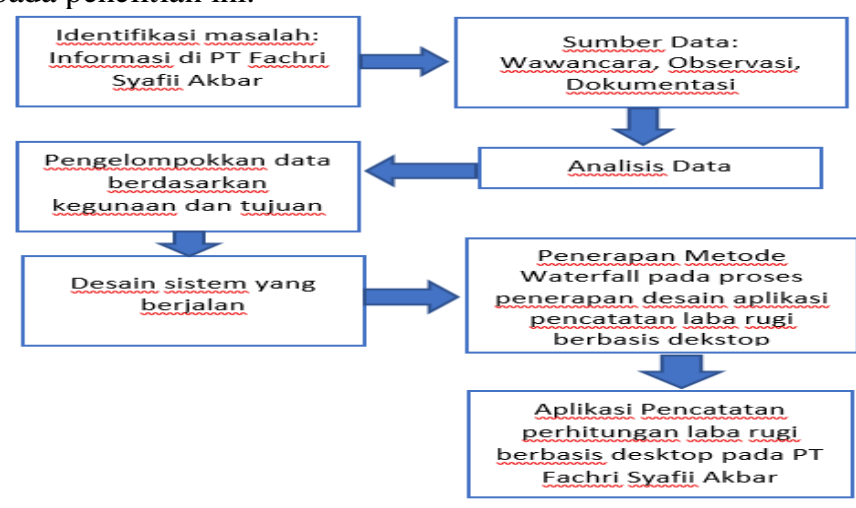

Gambar 1. Kerangka Pemikiran

\section{B. Bahan Penelitian}

Penelitian menggunakan data tentang proses dan prosedur pencatatan dokumentasi proyek. Dari data tersebut kemudian mendesain perangkat lunak yang selanjutnya digunakan sebagai acuan dalam input data proyek, input data barang proyek, input data keluar masuk barang proyek, dan laporan akhir. penelitian ini bertujuan membuat sebuah aplikasi yang dapat meningkatkan kegiatan dalam mencatat dan membuat laporan kegiatan proyek. Untuk itu dilakukan langkah-langkah penelitian sebagai berikut:

1. Menganalisa proses administrasi dan dokumentasi data yang dilakukan oleh bagian administrasi.

2. Melakukan perancangan sistem. Analisis sistem yang dimodelkan kedalam suatu bentuk rancangan sistem.

3. Membuat kesimpulan penelitian untuk mencapai solusi dan diharapkan diperoleh kesimpulan yang akan memenuhi tujuan penelitian.

Penelitian ini mengadopsi rekayasa perangkat lunak model waterfall [6]. Model waterfall adalah pendekatan klasik dalam 
pengembangan perangkat lunak yang menggambarkan pengembangan linier dan berurutan. Ini terdiri dari lima hingga tujuh fase dimana setiap fase didefinisikan oleh tugas dan tujuan yang berbeda, di mana keseluruhan fase di definisikan menggambarkan siklus hidup perangkat lunak sehingga pengirimannya. Setelah fase selesai, langkah pengembangan selanjutnya mengikuti dan hasil dari fase sebelumnya ke fase berikutnya.

Teknik pengumpulan data yang digunakan dalam penelitian ini ialah (1). Wawancara. (2) observasi, dan (2) studi pustaka [7]. Wawancara dilakukan dengan mengajukan beberapa pertanyaan seputar kinerja ataupun proses pencatatan dan laporan yang diterima dan diinput, wawancara dilakukan kepada pimpinan PT Fachri Syafii Akbar dan staff bagian administrasi. Observasi dilakukan dengan cara mengunjungi lokasi PT Fachri Syafii Akbar kemudian melihat, dan mempelajari kinerja sistem yang terjadi dilapangan kemudian mengubah proses tersebut dengan sistem. Studi pustaka merupakan metode dilakukan dengan cara mengumpulkan, membaca, dan mempelajari datadata yang ada dari berbagai media, seperti buku-buku, hasil karya tulis, jurnal-jurnal penelitian atau artikel-artikel dari internet yang berhubungan dengan masalah yang dibahas [8].

Studi literatur adalah sebuah proses penelitian yang dilakukan dengan mempelajari referensi yang bersumber dari jurnal, buku, karya ilmiah dan lain sebagainya dengan tujuan mendapatkan rreferensi dari penelitian sebelumnya agar penelitian saat ini menjadi lebih baik dari sebelumnya. [9]

\section{Alat Penelitian}

Dalam penelitian ini alat yang digunakan dalam membuat perancangan dan desain sistem pencatatan perhitungan laba rugi menggunakan Unified Modeling Language (UML). UML adalah himpunan struktur dan objek (OOP) Serta aplikasinya . UML digunakan untuk menentukan, menvisualisasikan, membangun, dan mendokemntasikan sistem informasi pada aplikasi pencatatan laba rugi.

\section{Metode Penelitian}

Metode penelitian yang digunakan pada penelitian ini adalah metode waterfall. Metode waterfall merupakan model pengembangan sistem informasi yang sistematik dan sekuensial. Metode waterfall memiliki tahapan-tahapan sebagai berikut [10]:

1. Requirements analysis and definition

Hasil yang diperoleh dari hasil konsultasi dengan bagian pengguna yang kemudian didefinisikan secara rinci dan berfungsi sebagai spesifikasi sistem.

2. System and software design

Tahapan perancangan sistem mengalokasikan kebutuhan sistem pada perangkat keras maupun perangkat lunak dengan membentuk arsitektur sistem secara keseluruhan.

3. Implementation and unit testing

Tahap ini, perancangan perangkat lunak direalisasikan sebagai serangkaian program atau unit program. Pengujian melibatkan verifikasi bahwa setiap unit memenuhi spesifikasinya.

4. Integration and system testing

Unit individu program atau program yang digabungkan dan diuji sebagai sebuah sistem lengkap untuk memastikan apakah sesuai dengan kebutuhan perangkat lunak atau tidak.

5. Operation and maintence

Tahapan ini adalah tahapan paling Panjang. Sistem dipasang dan digunakan secara nyata. Maintenance melibatkan pembetulan kesalahan yang tidak ditemukan pada tahapan-tahapan sebelumnya, meningkatkan implementasi dari unit sistem, dan meningkatkan layanan sistem sebagai kebutuhan baru.

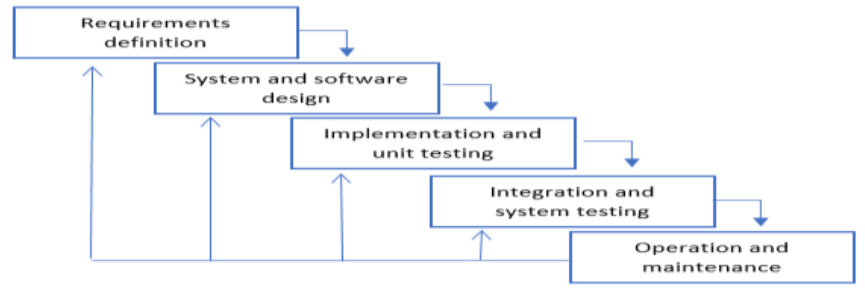

Gambar 2. Metode Waterfall

Gambar 2 adalah bagan metode waterfall yang merupakan metode pengambangan sistem yang digunakan pada penelitian ini.

\section{HASIL DAN PEMBAHASAN}

A. Analisa Kebutuhan

1. Identifikasi Masalah

Permasalahan yang terjadi pada proses pencatatan laba rugi pada PT Fachri Syafii Akbar diantaranya:

- Data yang telah ada maupun yang sedang diproses terkadang tidak terdokumentasi secara baik.

- Pada laporan akhir terjadi ketidaksesuaian hasil akhir diakibatkan pencatatan yang tidak tercatat.

- Pimpinan pada data meminta data laporan membutuhkan waktu dikarenakan proses yang digunakan pada lapangan masih menggunakan sistem manual.

2. Analisa Sistem

- Data yang tidak tercatat dengan baik secara menual beresiko terhadap ke-valid-an data yang masih sangat rendah, disamping itu juga efisiensi waktu dan keakuratan laporan menjadi tidak maksimal.

- Data yang dihasilkan setelah proses adalah informasi laporan laba rugi yang diperoleh dari hasil riwayat pencatatan keluar dan masuknya barang dalam penyelesaian suatu proyek.

- Informasi yang diperoleh di catat atau di input oleh Admin kemudian data yang telah terinput akan menjadi laporan yang dapat diakses oleh pimpinan.

\section{Kebutuhan Data}

Data yang dibutuhkan dalam desain sistem informasi pencatatan laba rugi di antaranya, data proyek, data pembelian, data pemakaian barang, dan laporan.

4. Kebutuhan fungsional

- Proses login untuk Admin 
- Proses login untuk pimpinan

- Pengelolaan data oleh admin : input, update, delete, dan edit.

- Pengelolaan data oleh pimpinan: view dan print.

\section{B. Desain sistem}

Berdasarkan dari hasil observasi, wawancara, dan kajian literatur diperoleh bahwa pelaksanaan pencatatan dan dokumentasi yang dilakukan pada PT Fachri Syafii Akbar masih dilakukan secara manual dan pengerjaan masih menggunakan kertas, belum menggunakan sistem komputerisasi [11]. Dari hasil ini maka dengan pendekatan sistem diperoleh diagram konteks.

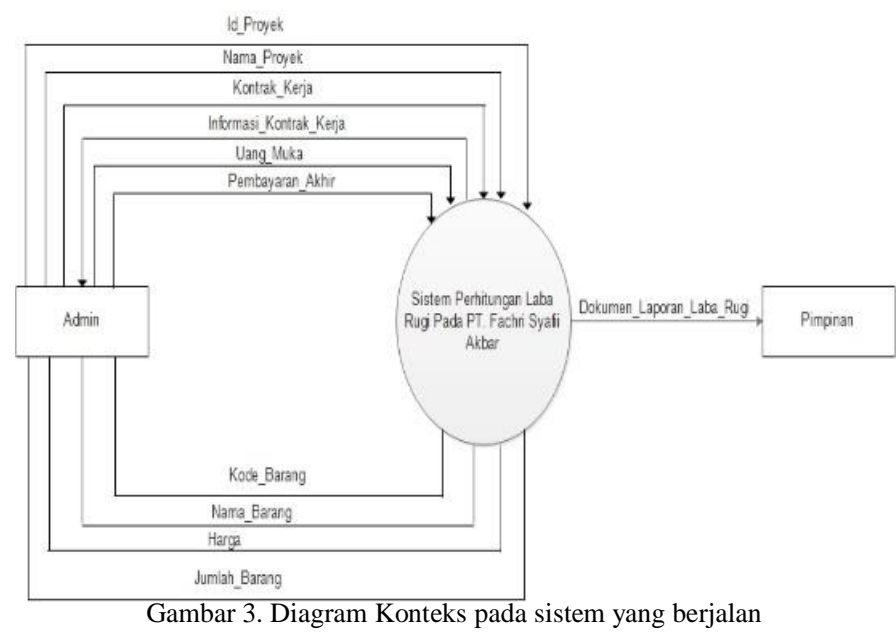

Berdasarkan gambar diagram konteks menunjukkan sistem perhitungan laba rugi pada pada PT Fachri Syafii Akbar memiliki 2 (Dua) terminator yaitu admin dan pimpinan. Data bersumber dari admin berupa konfigurasi data proyek dan data proses pengerjaan proyek. Sedangkan data yang diterima oleh pimpinan adalah dokumen laporan laba rugi yang diperoleh dari kesimpulan data proyek dan proses pengerjaan proyak.

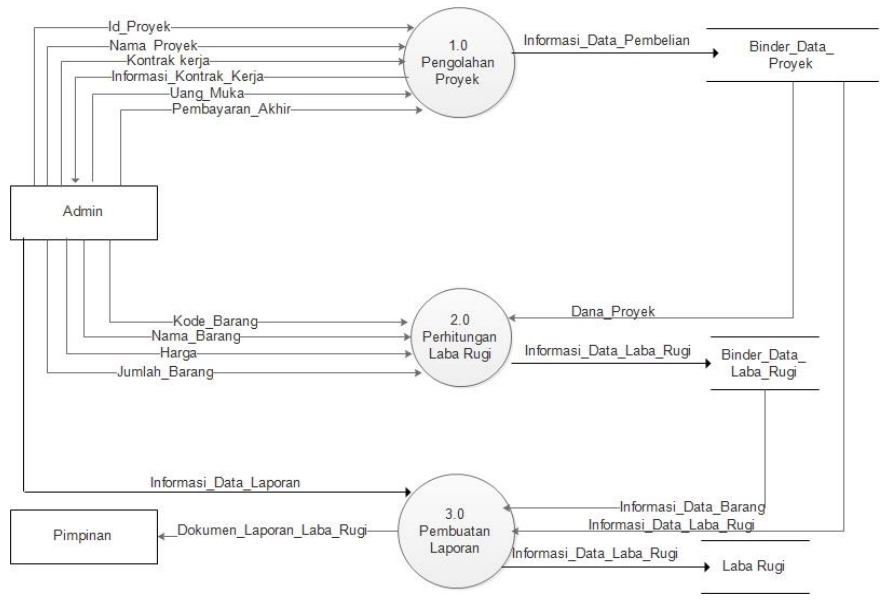

Gambar 4. Diagram Nol pada Sistem Berjalan

Diagram level 0 adalah diagram yang menunjukkan semua proses utama yang menyusun keseluruhan sistem, diagram ini didapat dari gambar 1. Berikut penjelasan diagram level o.
1. Diagram level 0 ini menunjukkan arus data level 0 dari lanjutan diagram konteks.

2. Proses 1.0 adalah proses input data konfigurasi data proyek yang bersumber dari admin, hasil proses disimpan dan dapat dilihat dalam file binder data proyek.

3. Proses 2.0 proses yang diinput oleh admin berasal dari data proses transaksi yang terjadi pada saat proyek dikerjakan hasil proses disimpan pada binder data laba rugi setelah disimpan data tersebut dapat telihat menjadi riwayat dapat dilihat pada binder data laba rugi.

4. Proses 3.0 proses pembuatan laporan data yang diperoleh berasal dari input admin yang menjadi nilai akhir suatu proses kemudian data tersebut di rangkum menjadi file yang tersimpan pada laba rugi. Kemudian pada proses 3.0 pimpinan dapat mengakses dokumen laporan laba rugi.

\section{Pembahasan Hasil Penelitian 1) Desain antamuka}

Hasil terakhir dari penelitian ini yaitu aplikasi perhitungan laba rugi berbasis desktop. Pada tampilan depan aplikasi didesain form login dengan tampilan menu awal pada saat memasuki menu utama. Pada tampilan form login digunakan dengan tujuan mengenali user yang akan mengakses aplikasi dikarenakan berdasarkan hasil rancangan sistem user yang dapat mengakses adalah admin dan pimpinan.

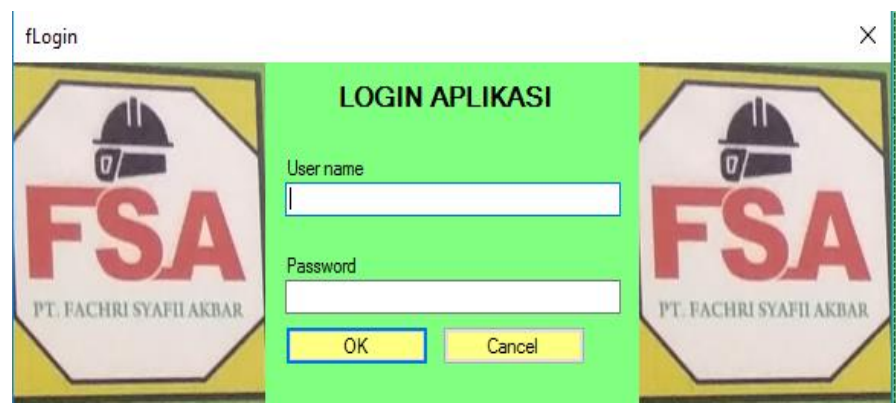

Gambar 5. Tampilan Halaman Login

Setelah user memasuki aplikasi akan muncul halaman menu utama. Halaman menu utama merupakan tampilan semua menu yang telah diimplementasi dari hasil observasi dan diagram konteks yang telah dirancang. Pada tampilan halaman menu, memiliki perbedaan antara admin dan pmpinan. Gambar 5 yang merupakan tampilan halaman menu untuk admin. Pada halaman menu untuk admin telihat jika admin dapat mengakses master menu, pengguna proyek, barang pembelian, biaya operasional, dan laporan.

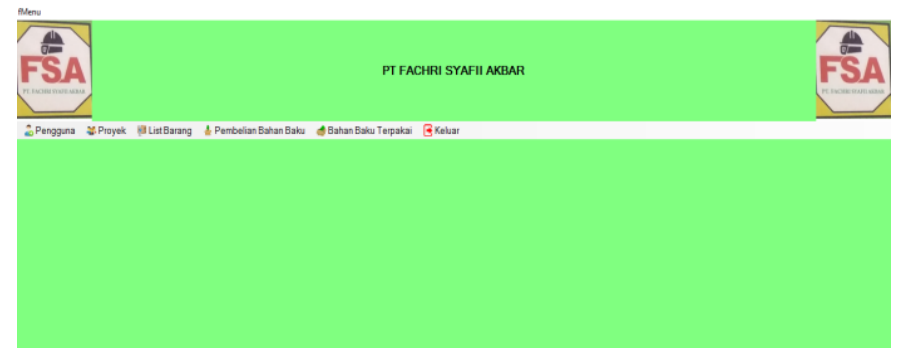

Gambar 6. Tampilan Halaman Menu Admin 
Tampilan halaman menu untuk pimpinan berbeda dengan yang telihat di Admin. Hal ini dikarenakan pimpinan tidak melakukan input, berdasarkan hasil observasi pimpinan hanya membutuhkan data yang diinput oleh Admin untuk melihat data proyek dan laporan proyek. Sehingga tampilan untuk pimpinan ditunjukkan pada gambar 7. Tampilan Halaman Menu Pimpinan.

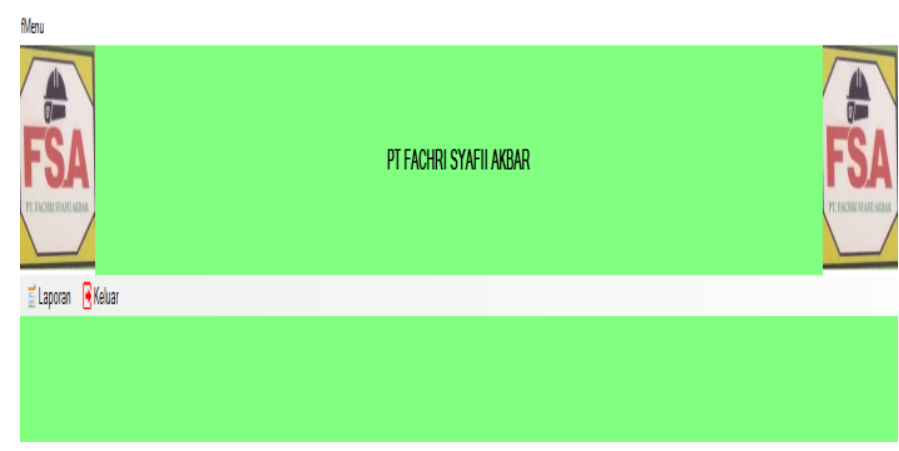

Gambar 7. Tampilan Halaman Menu Pimpinan

Pada proses 1.0 merupakan tampilan yang dirancang untuk Admin. Tampilan halaman data proyek menunjukkan data daftar proyek yang terdiri dari kode proyek, nama proyek, alamat proyek, alamat proyek, anggaran, tahun, nama pelanggan, alamat pelanggan, nomor telepon. Data ini diperoleh dari hasil dokumentasi pada saat observasi lapangan. Data ini dibutuhkan untuk menjadi acuan admin dalam menginput data dan memantau proses pengerjaan proyek yang telah diterima dan akan diselesaikan. Tampilan halaman untuk master data proyek pada gambar 8 menunjukkan Tampilan master data proyek.

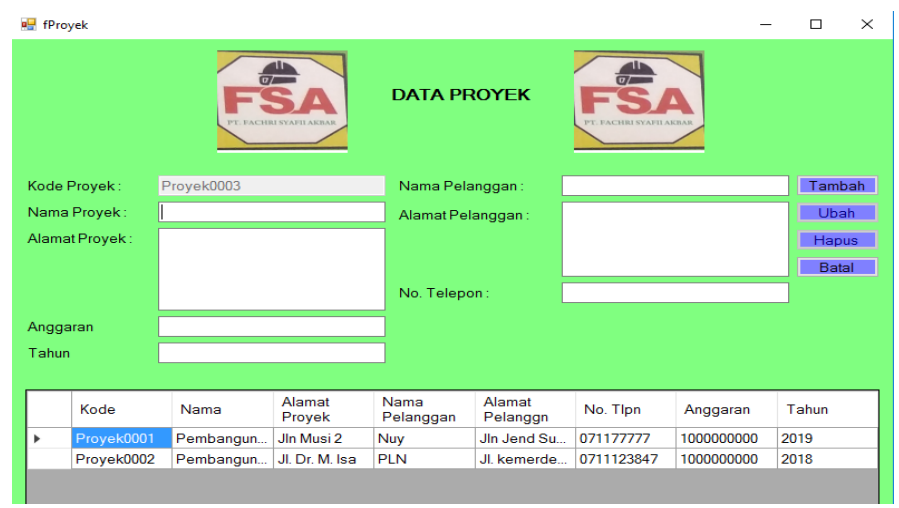

Gambar 8. Tampilan Master Data proyek

Pada proses 1.0 menunjukkan data yang telah diinput oleh Admin akan tersimpan pada binder data proyek. Pada binder data proyek jika diperlihatkan pada aplikasi maka yang akan terlihat adalah data proyek yang ada pada PT Fachri Syafii Akbar, baik yang lampau maupun yang ada saat ini. Untuk mempermudah Admin dalam pencarian data maka data proyek diberikan kode unik sehingga mempercepat proses pencarian data. Tampilan gambar 9 menunjukkan Tampilan cari data proyek.

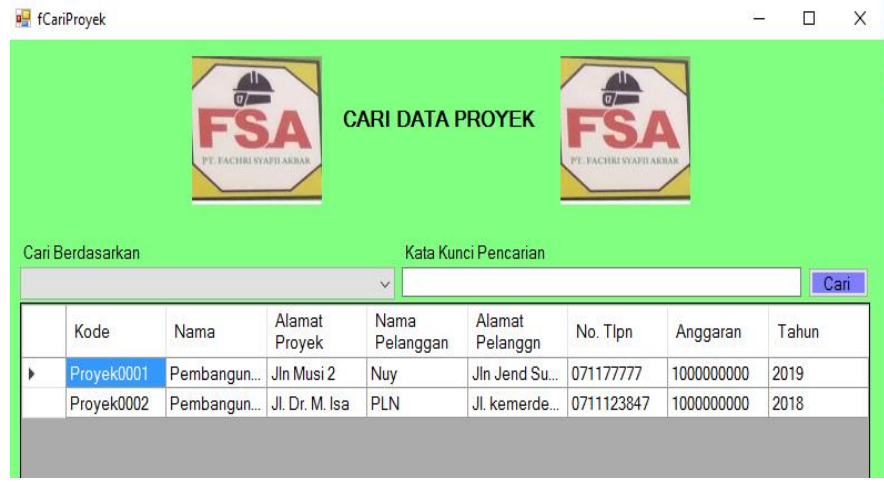

Gambar 9. Tampilan cari data proyek

Pada proses 2.0 terlihat Admin dapat melakukan input perhitungan laba rugi admin dapat input data barang. Untuk memudahkan Admin dalam input data barang maka diinput master data barang, hal ini bertujuan agar pada saat ada proyek yang serupa Admin tidak harus menginput nama barang secara manual tapi dengan adanya sistem Admin dapat dengan mudah dan cepat mencari dan input data yang akan diproses. Adapun tampilan master data barang pada gambar 10 menunjukkan Master data barang.

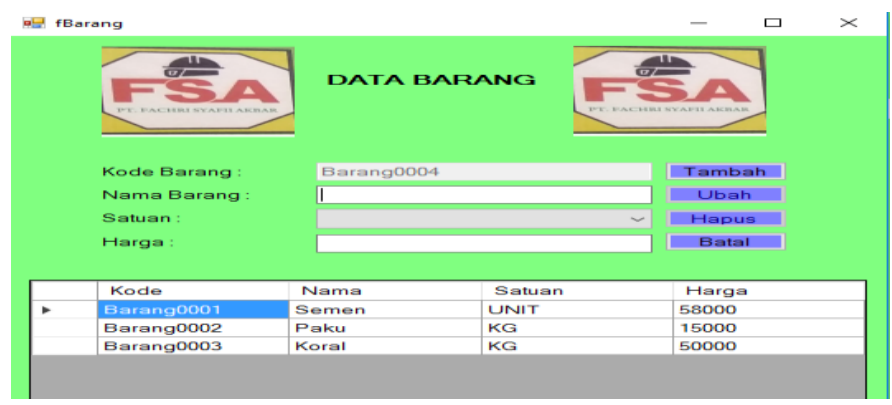

Gambar 10. Master Data Barang

Dengan adanya master barang, Admin yang akan menginput nama barang yang akan digunakan pada proyek yang berjalan dengan mudah, pada gambar 11 menunjukkan Tampilan Barang.

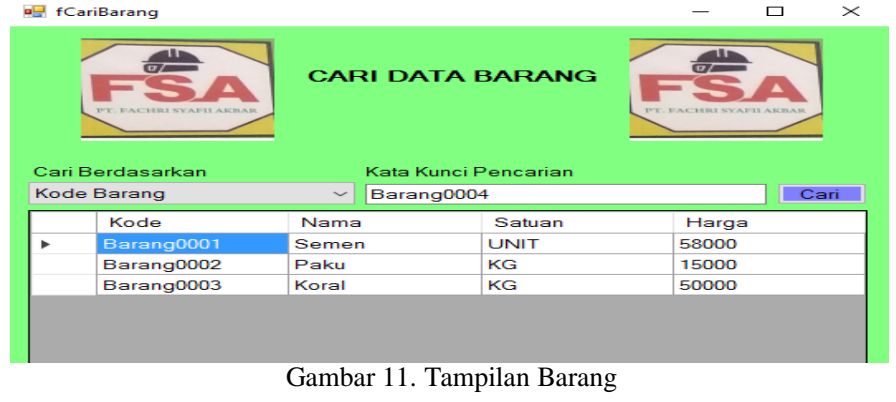

Data yang diinput oleh Admin merupakan data pembelian dan pengunaan bahan ataupun barang yang akan digunakan. Namun halaman untuk pembelian dan penggunaan dipisahkan pada tampilan yang berbeda. Hal ini bertujuan untuk memudahkan pada laporan akhir. tampilan pembelian terdiri dari kode barang, nama barang, harga jumlah, subtotal, kode transaksi, tanggal transaksi, kode proyek, nama proyek. Pada 
gambar 12 menunjukkan Tampilan pembelian.

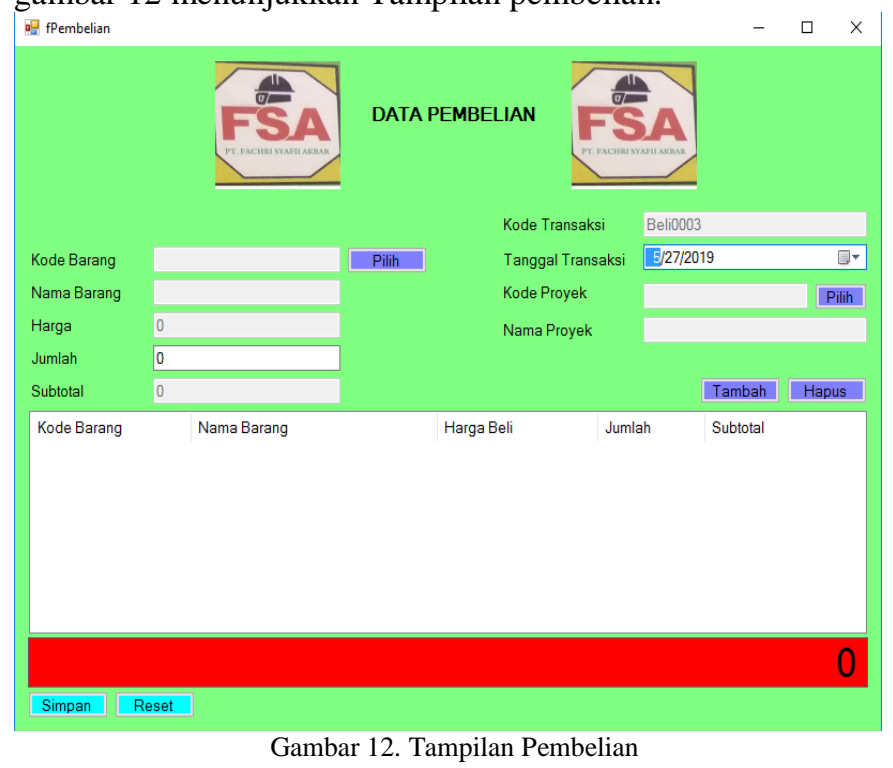

Data yang telah diinput akan terlihat pada data pembelian barang akan tersimpan pada tampilan pembelian. Pada gambar 13 menunjukkan Tampilan Data Pembelian.

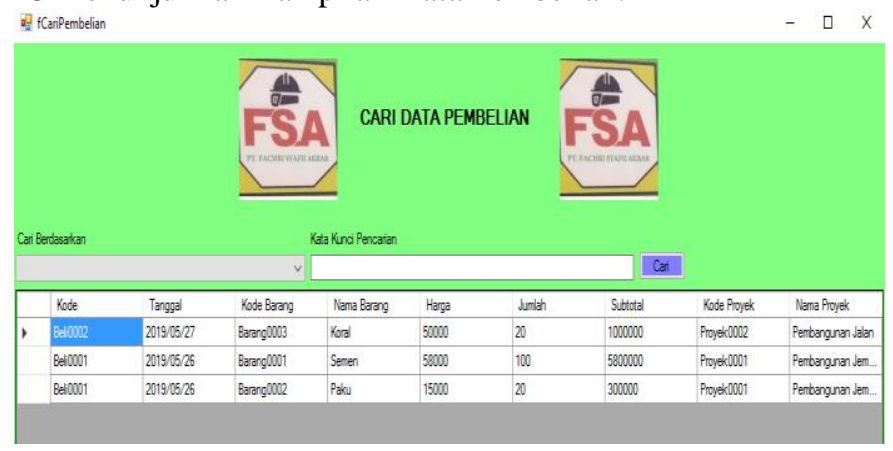

Gambar 13. Tampilan data pembelian

Jika barang dipakai atau dikeluarkan pada saat pengerjaan proyek maka data akan di kegiatan tersebut dapat di input oleh Admin pada halaman bahan baku terpakai. Gambar 14 menunjukkan Tampilan bahan baku terpakai.

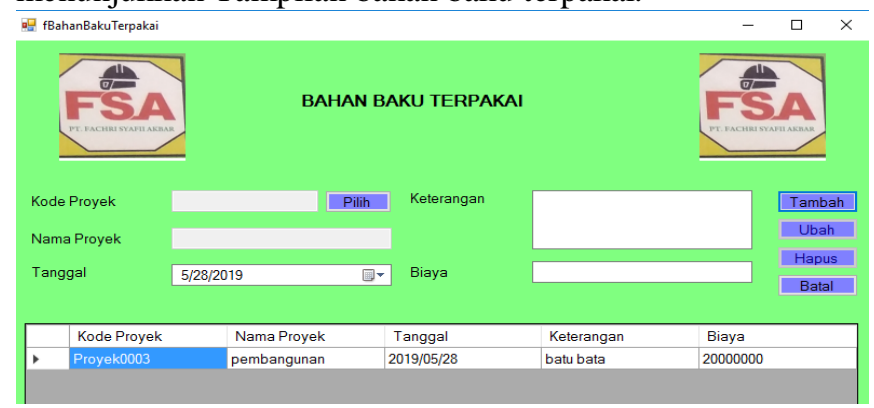

Gambar 14. Tampilan bahan baku terpakai

Proses 3.0 adalah proses dimana data yang telah diinput oleh Admin akan menghasilkan informasi dalam bentuk laporan yang akan disajikan kepada pimpinan. Adapun yang dilaporan kan adalah lapooran pembelian, laporan bahan baku, dan laporan laba rugi proyek. Tampilan pada laporan pembelian digambarkan pada gambar 15 yang menunjukkan Tampilan cetak laporan pembelian.

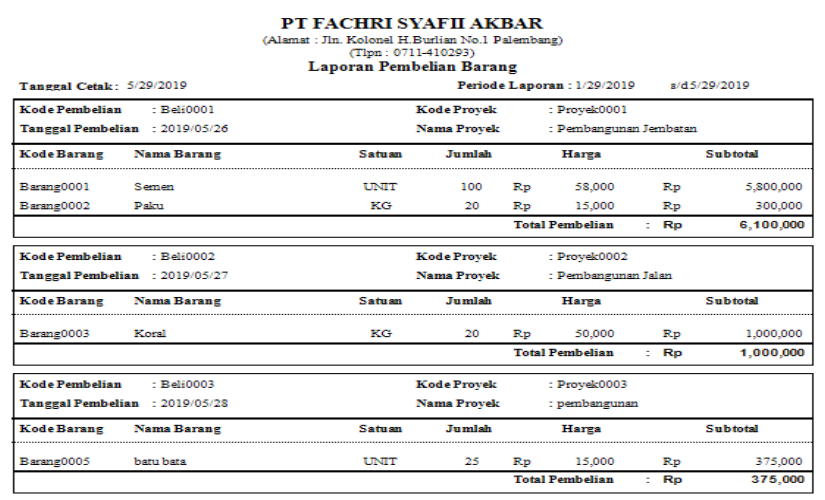

Gambar 15. Tampilan cetak laporan pembelian

Lampiran untuk laporan pembelian dapat dicetak dengan menu yang ada aplikasi serta dapat dipilih periode cetak berdasarkan kebutuhan informasi yang diinginkan. Tampilan halaman pemilihan menu dan cetak pada gambar 16 menunjukkan Laporan pembelian.

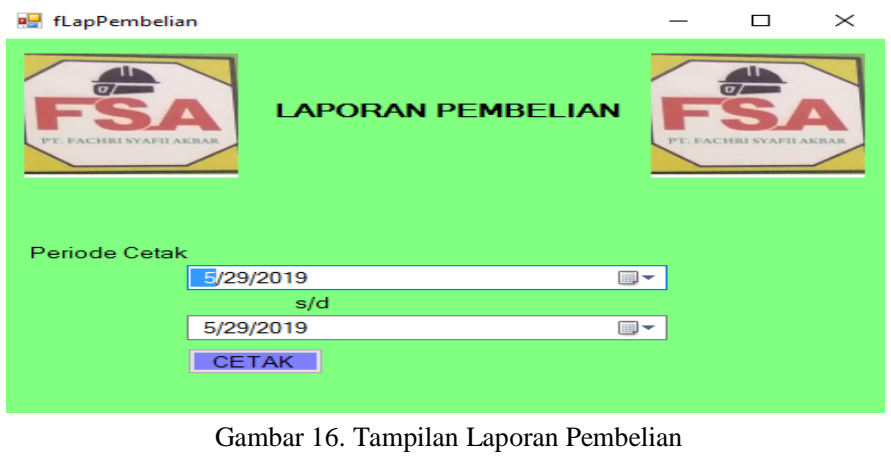

Laporan pembelian barang akan memperlihatkan data barang, alat, peralatan, perlengkapan, yang disediakan dan ada untuk proyek yang sedang berjalan dan telah dinyatakan selesai dalam bentuk pdf. Data ini diperoleh dari data yang diinput oleh Admin. Kemudian laporan yang diperlukan lainnya adalah laporan bahan baku, dimana laporan ini mengenai data barang atau transaksi yang keluar atau dipake pada saat proyek berjalan atau telah selesai. Gambar 17 menunujukkan Tampilan cetak data bahan baku terpakai.

\begin{tabular}{|c|c|c|c|c|c|}
\hline \multirow{2}{*}{\multicolumn{2}{|c|}{ Tanggal Cetak: 5/29/2019 }} & \multicolumn{2}{|c|}{$\begin{array}{c}\text { PT FACHRI SYAFII AKBAR } \\
\text { (Alamat: In Kolonel H.Burlian No.1 Palembang) } \\
\text { (Thn: 0711-410293) } \\
\text { Laporan Bahan Baku Terpakai }\end{array}$} & \multirow{3}{*}{ 1/29/2019 s/d 5/29/2019 } & \\
\hline & & & Periode Laporan : & & \\
\hline Tanggal & Kode Proyek & Nama Proyek & Keterangan Biaya & & Biaya \\
\hline $2019-05-28$ & Proyek0003 & pembangunan & batubata & $\mathrm{Rp}$ & $20,000,000$ \\
\hline
\end{tabular}

Gambar 17. Tampilan cetak data bahan baku terpakai. 
Tampilan laporan laba rugi merupakan laporan keseluruhan data proyek, pembelian dan penggunaan bahan baku pada saat proyek berjalan atau telah selesai. Sebelum informasi yang dibutuhkan muncul ditampilkan terlebih dahulu tampilan laporan laba rugi proyek pada gambar 18 menunjukkan Tampilan Laporan Laba Rugi Proyek.

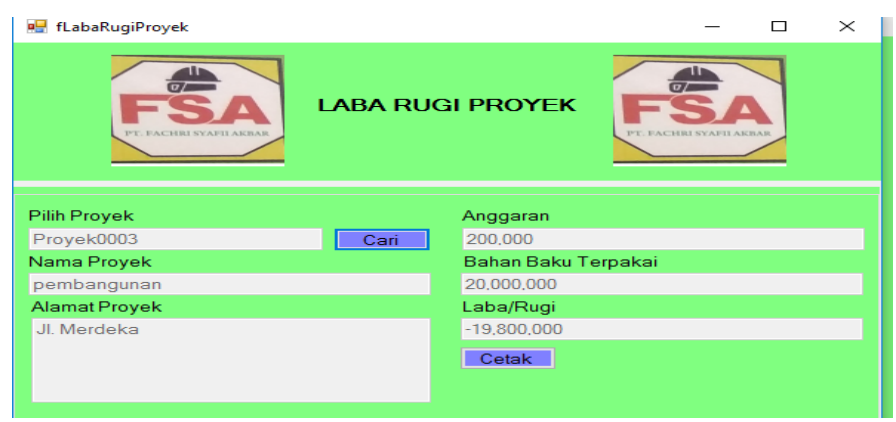

Gambar 18. Tampilan laporan laba rugi proyek

Jika data pada gambar 18 diisi maka akan muncul tampilan laporan laba rugi proyek seperti yang dibutuhkan. Kemudian data tersebut dapat dicetak. Hasil cetak laporan laba rugi seperti yang terlihat pada gambar 19. Laporan laba rugi dpaat diakses oleh pimpinan dan admin.

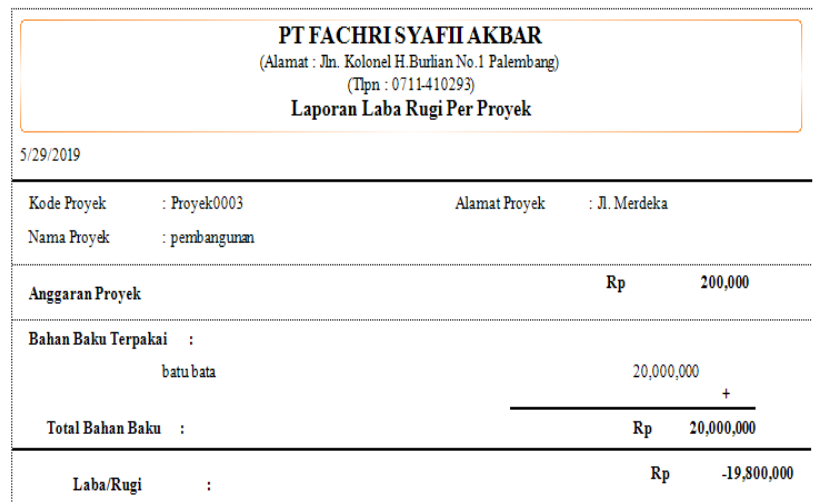

Gambar 19. Tampilan cetak laporan laba rugi proyek

\section{2) Integrasi dan pengujian sistem}

Pengujian integrase adalah Teknik untuk mengkontruksi struktur program dengan melakukan pengujian untuk mengungkap kesalahan sehubungan dengan menggabungkan modul-modul secara Bersama-sama. Intehrasi dilakukan dengan pendekatan top-down terhadap struktur program. Modul integrasikan dengan menggerakkan ke bawah melalui hirarki kontrol yang dimulai dari modul menu utama.

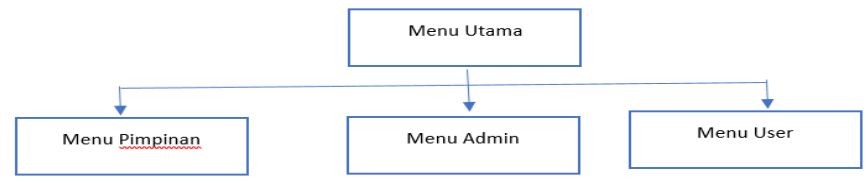

Gambar 20. Bagan Integrasi sistem

Pengujian sistem merupakan elemen kritis dari jaminan kualitas perangkat lunak dan merepresentasikan kajian pokok dari spesifikasi, desain dan pengkodean. Dalam penelitian ini pengujian sistem dilakukan dengan melakukan pengujian black-box. Pengujian black-box merupakan salah satu pengujian aplikasi atau perangkat lunak yang berfokus pada persyaratan fungsional perangkat lunak [12]. Karena uji coba black-box memungkinkan pengembangan software untuk membuat himpunan kondisi input yang melatih seluruh syaratsyarat fungsional program aplikasi pencatatan perhitungan laba rugi.

\section{3) Operasional dan Perawatan}

Operasional aplikasi dilakukan di PT Fachri Syafii Akbar. Sedangkan pemeliharaan sistem dilakukan pemeriksaan secara periodic terhadap data pada aplikasi.

\section{PENUTUP}

Berdasarkan hasil dan pembahasan yang telah dijabarkan, maka dapat diambil beberapa kesimpulan sebagai hasil dari penelitian sebagai berikut:

Metode waterfall dapat digunakan metode yang digunakan untuk mengadaptasi kegiatan manual yang dilakukan didalam proses sistem berjalan di PT. Fachri Syafii Akbar kemudian diimplementasikan kedalam sistem pencatatan laba rugi.

Proses yang terjadi pada PT. Fachri Syafii Akbar diubah kedalam sistem berbasis desktop disesuaikan dengan kegiatan yang terjadi sehingga memudahkan pengguna beradaptasi dan menggunakan aplikasi tersebut. Pada hasil informasi yang dihasilkan gambar 17 pada saat diuji coba berhasil menunjukkan laporan laba raugi dimana dapat diambil kesimpulan proyek tersebut mengalami kerugian. Dengan hasil ini, pimpinan dapat mengambil keputusan terkait kebutuhan dan kelangsungan proyek.

Dengan demikian aplikasi berbasis desktop disimpukan dapat membantu PT. Fachri Syafii Akbar dalam melakukan pencatatan data proyek, kegiatan, hingga laporan. Hal ini menjawab permasalahan yang terjadi di PT. Fachri Syafii Akbar. Dengan menggunakan aplikasi berbasis desktop diharapkan dapat membantu dan mempermudah kegiatan pencatatan dan pelaporan.

\section{REFERENCES}

[1] H. Ferieka, "Akuntansi sebagai suatu Siklus. ISLAMICONOMIC," $J$. Ekon. Islam, vol. 4, no. 2, pp. 1-15, 2013.

[2] I. M. Sarjana, B. Susrusa, and D. P. Darmawan, "Analisis Kinerja Keuangan pada Koperasi Serba Usaha di Kabupaten Buleleng," J. Manaj. Agribisnis, vol. 1, no. 2, pp. 16-22, 2013.

[3] E. N. Fitriana, "Analisis Atas Pengakuan Pendapatan Pada Perusahaan Jasa Kontruksi Kaitannya Terhadap Laporan Laba Rugi Perusahaan," 2015.

[4] M. Salahuddin and A. S. Rosa, Modul Pembelajaran Rekayasa Perangkat Lunak (Terstruktur dan Berorientasi Objek). Bandung: Modula, 2011.

[5] M. Christianti and L. Wijaya, "Penjualan Obat dan Laporan Keuangan dengan Menerapkan Manajemen Persediaan," J. Sist. Informasi2, vol. 6, no. 2, pp. 127-141, 11AD.

[6] C. Larman, Applying UML and Patterns: An Introduction to ObjectOriented Analysis and Design and Iterative Development, Third Edition. United States of America: Addison Wesley Professional, 2004.

[7] H. Hasanah, "TEKNIK-TEKNIK OBSERVASI (Sebuah Alternatif 
Metode Pengumpulan Data Kualitatif Ilmu-ilmu Sosial)," J. AtTaqaddum, vol. 8, no. 1, 2016.

[8] Indrajani, Perancangan Basis Data dalam All in 1. Jakarta: Elek Media Komputindo, 2011

[9] N. Wijaya, "PERANCANGAN APLIKASI PROMOSI SONGKET PALEMBANG BERBASIS ANDROID," JUSIM, vol. 2, no. 2, pp. 1022, 2017.

[10] F. Al Hanif, Analisis dan Perancagan Sistem Informasi. Yogyakarta: Andi Offset, 2007.
[11] N. K. Sumiari and P. Setyarini, "Perancangan Media Publikasi Kesenian Tari Bali Berbasis Web," in Konferensi Nasional Sistem dan Informatika (KNS\&I), 2015.

[12] M. Si. Mustaqbal, R. F. Firdaus, and H. Rahmadi, "Pengujian Aplikasi Menggunakan Black Box Testing Boundary Value Analysis," J. Ilm. Teknol. Inf. Terap., vol. 1, no. 3, pp. 31-36, 2015. 